\section{Identification and Isolation of the Specific Allergens from Mutton by Western Blot, Chromatography and MALDI-TOF/TOF-MS}

\author{
Jia Chen*, Yuanxi Deng and Hui Xu \\ Department of Food and Bioengineering, Bengbu College, Bengbu, 233030, China
}

\begin{abstract}
A B S T R A C T
To study the specific allergen in mutton, soluble protein from mutton was extracted, and separated by SDS-PAGE. With the positive and negative sera of rats, the special allergen was identified with the Western Blot, showing that the $12 \mathrm{kDa}$ was the specific allergen. The protein of $12 \mathrm{kDa}$ was then analyzed by ion exchange and gel filtration chromatography, and the MALDI-TOF/TOF-MS search on the Internet. The results indicate that the protein was diamine- $\mathrm{N}$-acetyltransferase.
\end{abstract}
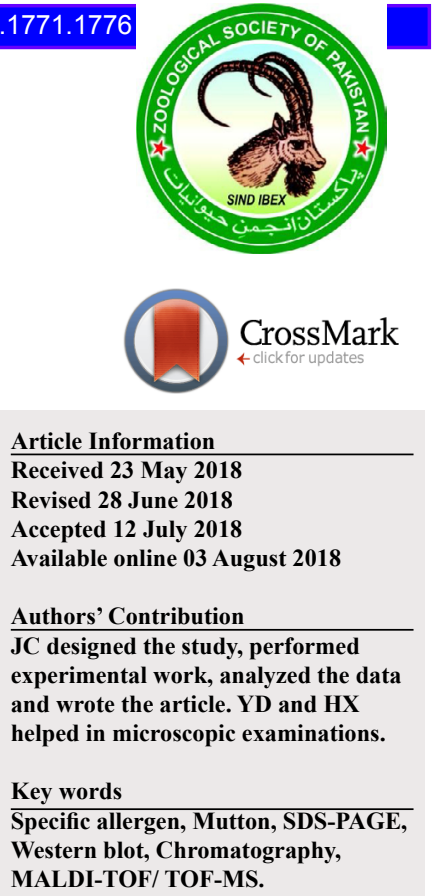

\section{INTRODUCTION}

A food allergy is the especially structural features of dietary composition, inappropriate and harmful response to immune system. Normally, food hypersensitive reactions are harmless, however, in susceptible individuals; adverse reactions can range from mild skin reactions to severe illness, even to life-threatening reactions (Guo et al., 2018). Adverse reaction to food is the general term applied to a clinically abnormal response and may be mediated by immunologic, pharmacologic, toxic, infectious, idiosyncratic, metabolic and neuropsychologic mechanisms. Simultaneously, the frequency of adverse reactions is very low, because of the general variation in dietary habits and low concentration of possible toxins in food (Ispano et al., 1998). Moreover, toxic food reactions always give neurologic symptoms, or abnormalities with hepatic or hematopoietic function (May, 1983).

Food allergies or hypersensitivity affects a large group of the general population in the word. It is the biggest reason of anaphylaxis evaluated in the emergency department in all age groups, and the number of hospitalizations for food-induced anaphylaxis has increased more than 3-fold in the past research (Gupta et al., 2007; Decker et al., 2008). The studies hold that more than $20 \%$ of sick person insist in believing themselves to be allergic to food (Young et al., 1994), the ratio of this disorder phenomenon about

\footnotetext{
* Corresponding author: bojourjia@163.com 0030-9923/2018/0005-1771 \$ 9.00/0

Copyright 2018 Zoological Society of Pakistan
}

3\% or 4\% (Kanny et al., 2001; Sicherer et al., 2004). Food allergy accounts for up to $50 \%$ of all anaphylactic episodes resulting in hospitalization and represents the major cause for these hazardous reactions (Brown et al., 2001; Sampson, 2000; Smit et al., 2005). Owing to the increasing number of food-allergic patients, severity results of foodinduced adverse reactions, or is accompanied by acute and chronicity of some hypersensitivities and inflammation. prevalence of food allergies, potential severity of reactions and chronicity of some hypersensitivities, antigenic activity of food now is considered as focus point issue in humanity public health (Untersmayr and Jensen-Jarolim, 2008; Samarten et al., 2001).

Increasing consumers' demand for a nutritionally balanced and safe foods has led to mutton becoming popular as it provides a major source of protein, many vitamins and minerals (Li et al., 2005; Williams, 2007). Proteins from mutton were the substantial nutrients for people. So far, some nutritionists analyzed and evaluated the nutrient contribution of mutton to balance of diet and nutrition, but there are other studies that have shown associations between mutton intake and adverse food reactions. Mutton is an important meat resource for human, but it also a commonly cause of food hypersensitivity. In particular, some patients with food allergies are sensitive to mutton. Food allergy is caused by food protei and then induces a series of immune response (Untersmayr and Jensen-Jarolim, 2008). Food's protein is the most common allergic component and is discerned as potentially threat for immune system. Note that, when and only dietary proteins will be large enough to elicit immune responses, 
food's protein is considered or analyzed as potential food allergens. Some studies have indicated that seem to be a precondition for the induction of immediate type I immune responses.

To our knowledge, the identification, purification and isolation of the specific allergens from mutton is rarely reported. With this background and knowledge of immunological theory to figure out the specific allergen of mutton, the purpose of this article was to separate and identify immunoreactive substance of mutton by using proteomic analysis.

\section{MATERIALS AND METHODS}

\section{Preparation of crude protein extract from mutton}

Mutton was obtained from the local market. Fresh mutton had been cut into small pieces with ophthalmic scissors was boiled in phosphate buffered saline (PBS), pH7.2 (1:5, weight/volume) (including $100 \mu \mathrm{g} / \mathrm{mL}$ PMSF) for $3 \mathrm{~h}$ at room. And raw extract was followed by homogenization using a Waring blender. Homogenate was centrifuged at $12000 \mathrm{~g}, 30 \mathrm{~min}, 4^{\circ} \mathrm{C}$. The clear supernatant was collected as the mutton crude protein extract for the next process.

\section{Preparation of anti-serum}

Serum was obtained from SD rats with dietary mutton for 4 weeks and concentrations of IgE in rats' serum was determined as an allergen and used in this study. The serum was used for Western blot without dilution. All extraction and purification procedures were performed at $4{ }^{\circ} \mathrm{C}$.

\section{SDS-PAGE analysis}

SDS-PAGE was performed using a $12 \%$ polyacrylamide separating gel and a stacking gel of 5\%. Electrophoresis was carried out with a Mini Protean 3 Apparatus (Bio-Rad, USA). Each sample was dissolved with Laemmli sample buffer (Bio-Rad, USA) in the presence of $5 \%$ 2-mercapto-ethanol, heated at $95^{\circ} \mathrm{C}, 5$ min in water bath and subjected to electrophoresis. The protein marker (Bio-Rad, USA) was run along with samples as a control. The volume of samples loading was $10 \mu \mathrm{L}$ and electricity was $80 \mathrm{~V}$ in stacking gel and $120 \mathrm{~V}$ in separating gel. After electrophoresis, the gel was stained by Coomassie brilliant blue R-250. Protein masses were appraised by comparing the mutton protein bands with a marker using BIO-RAD Gel Doc 2000 and Quantity One software (Bio-Rad, USA).

\section{Western blot}

After SDS-PAGE, the separated proteins were electro transferred from the gel to Polyvinylidene fluoride
(PVDF, Bio-Rad, USA) membrane using Semi-Dry Electrophoretic Transfer systerm at $12 \mathrm{~V}$ for $28 \mathrm{~min}$. Immunoblotting assay of IgE binding was prepared with crude extracts from mutton. The non-specific sites were blocked with 5\% skimmed milk in TBS. After washing with Tris-buffered saline (containing $0.05 \%$ Tween 20), the transfer membrane was incubated with individual rat's serum at $4{ }^{\circ} \mathrm{C}, 12 \mathrm{~h}$. IgE binding proteins were checked by using HRP-labeled goat anti-mouse $\operatorname{IgE}$ antibody (Sigma, USA) followed by incubation for $30 \mathrm{~min}$ at room $22{ }^{\circ} \mathrm{C}-24{ }^{\circ} \mathrm{C}$ in dark. At last, TMB Substrate Kit $(3,3,5$, 5etramethylbenzidine) (Pierce, USA) was experimented for color. Negative control was the serum from nonallergic subject.

\section{Purification and isolation of the major allergen}

Mutton crude protein extract was applied to a $1.5 \times 18 \mathrm{~cm}$ column of DEAE- 52 cellulose (Whatman) that had been preequilibrated with $20 \mathrm{mM}$ Piperazine buffer (pH 6.0). $2 \mathrm{~mL}$ of sample was applied and the column was equilibrated by same buffer. Bound proteins were eluted with a linear $\mathrm{NaCl}$ gradient $(0.5 \mathrm{~mol} / \mathrm{L}$ to $1.0 \mathrm{~mol} / \mathrm{L})$ at a flow rate of $1.0 \mathrm{~mL} / \mathrm{min}$. Elution were followed by continuous monitoring at $280 \mathrm{~nm}$. Fractions were collected from each peak, after measuring the concentrations of their protein, these fractions were performed to SDS-PAGE and immunoblotting for detecting the allergenic activity.

Those with allergenic activity from fraction 2 were applied to a $1.5 \times 18 \mathrm{~cm}$ column of Sephadex G-75(Amersham) that was equilibrated with PBS 0.01 $\mathrm{mol} / \mathrm{L}(\mathrm{pH}$ 7.0). The elution was recorded by continuous monitoring at $280 \mathrm{~nm}$ and $10 \mathrm{~mL}$ fractions from peak were collected. After concentration and measurement of the protein concentrations, the fraction was analyzed by SDSPAGE and immunoblotting.

\section{Identification of allergenic activity protein}

The protein band identified on immunoblotting were excised from the gel and transferred to micro-centrifuge tubes with distilled water. Protein sample was bleached by $50 \mathrm{mM}$ Ammonium bicarbonate solution including 50\% Acetonitrile for $20 \mathrm{~min}$ and then dried. After digesting with trypsin, the protein fractions were analyzed by matrix-assisted laser desorption-ionization time of flight (MALDI-TOF/TOF) tandem mass spectrometer with 4700 Proteomics Analyzer. The sample irradiated with a $\mathrm{N}_{2}$ laser (335nm, 150ns pulse) and each pulse was accelerated by a $20 \mathrm{kV}$ using a positive reflection ion mode. Spectra were analyzed to identify protein fractions by Mascot sequence matching software (Matrix Science) with National Center for Biotechnology Information (NCBI) Database (Richard and Simpson, 2002). 


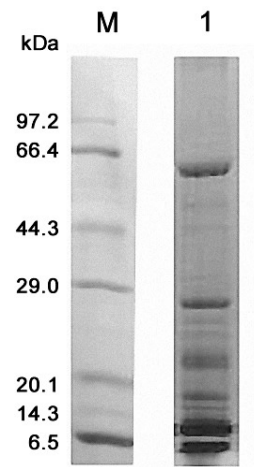

Fig. 1. The SDS-PAGE profile of crude protein extracts from mutton. M, marker; 1 , protein extracts from mutton.

\section{RESULTS}

The SDS-PAGE profile of mutton crude protein extract, followed by staining of the gel, it gave at least 12 protein bands from $6 \mathrm{kda}$ to $100 \mathrm{kda}$. The most prominent bands were about $6 \mathrm{kda}, 12 \mathrm{kd}, 25 \mathrm{kda}$ and $40 \mathrm{kda}$ (Fig. 1).

To isolation the allergenic protein, the protein band in a raw extract was transferred to a PVDF membrane from SDS-PAGE gel and subsequently, subjected to immunoblotting. Figure 2 reported the immunoblotting of mutton crude protein extract with the anti-serum and nonallergic serum, showing the allergenic protein of the band about $12 \mathrm{kd}$. On the other hand, none of the protein bands that were incubated with non-allergic serum as a negative control were observed (band not shown).

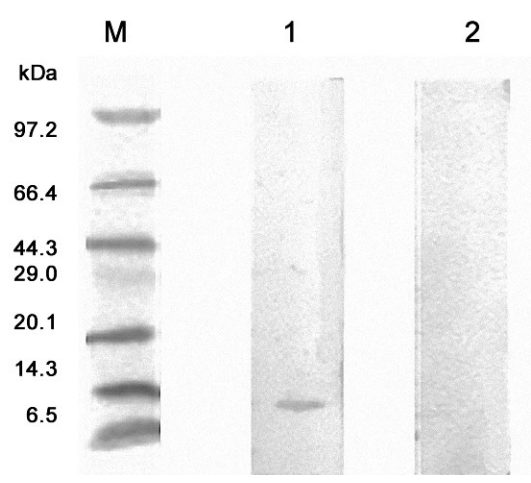

Fig. 2. The western blot profile of protein extracts with sera from rats. $\mathrm{M}$, marker; 1 , positive sera; 2 , negative sera.

The mutton crude protein extract was fractionated by ion-exchange chromatography (DEAE-52 cellulose) with a linear $\mathrm{NaCl}$ gradient and divided into four fractions (Fig. 3). After concentration of their protein fractions, the fraction 2 was shown the allergenic activity by Immunoblotting. This fraction was further purified by gel filtration chromatography (Sephadex G-75) with PBS $0.01 \mathrm{~mol} / \mathrm{L}$, pH7.0 (Fig. 4). The fraction A was purified in fractions 2 and submitted to SDS-PAGE.

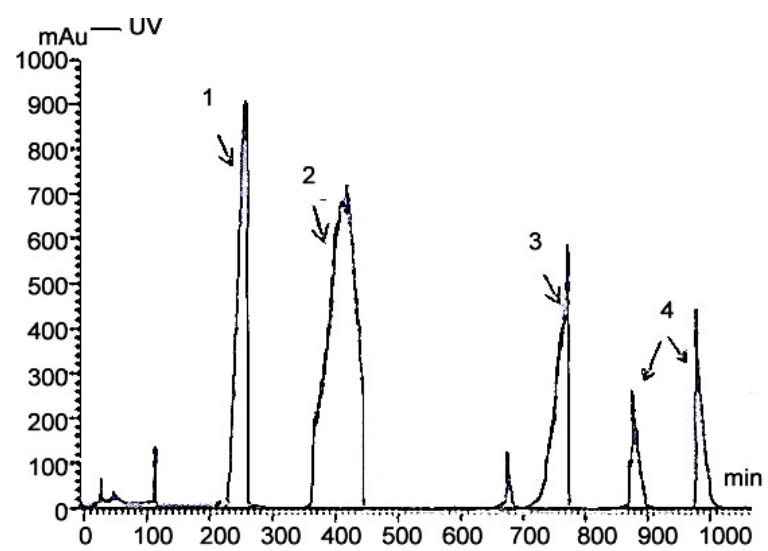

Fig. 3. Ion-exchange chromatography (DEAE-52 cellulose) of crude protein extract from mutton with a linear $\mathrm{NaCI}$ gradient and divided into four fractions.

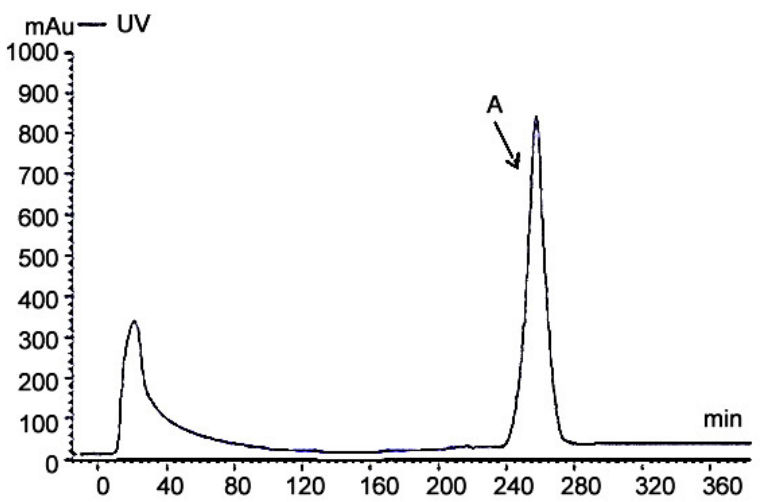

Fig. 4. Purification of peak 2 on Gel filtration chromatography Sephadex G-75 (Flow-rate, $1.0 \mathrm{~mL} / \mathrm{min}$; fraction volume, $10 \mathrm{~mL}$ ).

To identify the allergenic activity protein, when the gel was excised and digested with trypsin, it was analyzed by MALDI-TOF/TOF-MS. The results of spectra were submitted to NCBI protein databases to identify peptides in the light of their fragment masses. The protein identification was verified by precise of peptide fragments and quality of mass spectrum. By comparison with established databases, the MS profile was showed in Table I. Each peptide fragment was assigned a ladder score and a probability based score algorithm that gave an indication for the reliability of the peptide identification. The MS profile of the peptides from fraction $\mathrm{A}$, the $12.208 \mathrm{kda}$ protein, was showed high similarity with diamine $\mathrm{N}$-acetyltransferase from mutton. 
Table I.- Identification and bioinformatic analysis of the purified protein by MALDI-TOF/TOF-MS

Identification of the purified protein by MALDI-TOF/TOF-MS

\begin{tabular}{cccccc}
\hline 1 & SVVALDVAKN & WRSVVALDVA & KLAMGLYESF & GFRNLHICEV & TAKNWRFMID \\
51 & QQYAGKGYAK & LLIQFLQEKF & ECKMNLHICE & VTAKNWRFEC & KIIYLSLHPD \\
101 & NKKEAGDNAS & DDKSDDGSES & ESEKGTNGTS & EHVNGSNGER & ESVAAHKDEV \\
151 & APVESKQDER & SDDGSESESE & KEAGDNASDD & KAHSPDSRET & TDHESKNGND \\
201 & EPVIKYFNCN & LKMDYIFLRR & QWELQFANKV & EYAKELLHAG & KQVFLDSELS \\
251 & LKKEQNNSLL & ESMIYVEQNN & SLLESMIYVC & GFASRSAFYA & SFSKCSLEEL \\
301 & PQRCGFASRK & FSVMIDTNQT & YLSNVVNKYF & NCNLKMDYLF & LRRQWELQFA \\
351 & NKVEYAKELL & HAGKQVFLDS & ELSLKKEQNN & SLLESMIYVC & GFASRSAFYA \\
\hline
\end{tabular}

Bioinformatic analysis on the purified $12 \mathrm{kda}$ protein

\begin{tabular}{lccl}
\hline Accession No. & Molecular mass & Score & Describe \\
\hline gi|218234692 & 12208 & 120 & putative diamine N-acetyltransferase [Bacillus cereusB4264] \\
gi|30020157 & 12173 & 120 & Spermine/spermidine acetyltransferase [Bacillus cereusATCC 14579] \\
gi|206972099 & 12212 & 119 & putative diamine N-acetyltransferase [Bacillus cereusAH1134] \\
gi|212692580 & 14647 & 119 & hypothetical protein BACDOR-02077 [Bacteroides dorei DSM 17855] \\
gi|150003792 & 14649 & 110 & hypothetical protein BVU-1224 [Bacteroides vulgatus] \\
\hline
\end{tabular}

\section{DISCUSSIONS}

In this study we described a $12.208 \mathrm{kda}$ protein from mutton crude protein extract by SDS-PAGE and Immunoblotting as an allergenic activity protein, Ion exchange and Size exclusion chromatography were used to separation and purification.

IES could separate of the ions and polar molecules by their different charge. Protein is a special functional macromolecule, which contains both positive and negative charges. By altering the $\mathrm{pH}$ or the ionic concentration of the mobile phase, fattaginous protein molecules could be separated. In addition, it can be used for detaching any kind of charged molecule including small nucleotides and amino acids (Hamish, 1989; Weiss, 2005; Gjerde and Fritz, 2000; Robards et al., 1995). In first step, IEC was used for simple separation and purification of the mutton crude protein extract. With elution of a linear $\mathrm{NaCl}$ gradient $(0.5 \mathrm{~mol} / \mathrm{L}$ to $1.0 \mathrm{~mol} / \mathrm{L})$, the peak $1-4$ were collected and the fractions were carried out Immunoblotting to detect allergenic activity. The resulting showed that the peak 2 was represented the allergenic activity. From Figure 3, IEC provided good isolation results for mutton crude protein extract initially. SEC also is a chromatographic separation method, it can separate the molecules in solution by their size, and molecular weight (Stephanie et al., 2007). Usually, it is placed in the final step of purification, because of its low resolution chromatography and not discern similar species exactly.
But the superiority of this method is that it could be offered good separation of large molecules from the small molecules (Skoog, 2007), and all kinds of solutions could be applied on the filter without any effects, all biological activity of the particles could be preserved. If there are short, well-defined separation times and narrow bands, SECcould lead to good sensitivity. From Figure 4, with elution of PBS $0.01 \mathrm{~mol} / \mathrm{L}(\mathrm{pH} 7.0)$, SEC provided good purification results for the allergenic activity protein.

For instance, matrix-assisted laser desorption/ ionization time-of-flight or electrospray ionization mass spectrometry, Mass spectrometric methods is enthusiastically applied to the analysis of posttranslational protein mechanizations. Compared to other analysis, MALDI-TOF MS of peptides begets principally singlecharged ions (Mann and Jensen, 2003; Karas and Kruger, 2003). The results of peptides's masses are measured by MS, MALDI-TOF and matched to peptide masses that have been generated theoretically from proteins in databases (Samyn et al., 2004). Currently, the chief method of identify proteins from multiple samples is Tandem mass spectrometry (MS/MS). A focus of proteomics research is how to establish the acceptable confidence measures for the assignment of protein's identification from an unknown sample (Falkner et al., 2007; Soga and Heiger, 2000; Piraud et al., 2003; Heerma and Kulik, 1988).

After analyzing by MALDI-TOF/TOF-MS, the spectra of purified allergenic activity protein were obtained and subjected to NCBI protein databases. The resulting 
showed that the $12.208 \mathrm{kda}$ protein was high similarity with diamine $\mathrm{N}$-acetyltransferase. In enzymology, $\mathrm{N}$-acetyltransferase is an enzyme, it could catalyze the transfer of acetyl groups from acetyl-CoA to arylamines (Evans, 1989). It has extensive specificity for aromatic amines, particularly serotonin, and catalyze acetyl transfer to arylamines without CoA, belongs to the family of transferases (Ragione and Pegg, 1982). There are two NAT isozymes in humans, NAT1 and NAT2, both of which are now known to be polymorphic (Vatsis et al., 1995). There has been a lot of discussion on the role of NAT polymorphism in determining susceptibility to cancer, such as colorectal cancer, prostate cancer and breast cancer. Most of the investigations of NAT as a susceptibility factor in cancer have involved NAT2 polymorphism as it has been better characterized than NAT1 polymorphism (Wohlleb et al., 1990; Hein, 2002).

\section{CONCLUSIONS}

From immunoblotting, there was a $12 \mathrm{kda}$ protein in mutton that was identified as the special allergen with the positive and negative sera of rats. Identification of the result indicated that protein fragment was diamine $\mathrm{N}$-acetyltransferase by using MALDI-TOF/TOF MS .This method is simply, effective and time-saving.

\section{ACKNOWLEDGMENT}

We acknowledge the financial supports of 2016-Key point of university's natural science project and 2016key point of Visiting Program of AnHui under Grant No.KJ2016A451 (Study on the function and mechanism of immune substance in Mutton) and No. gxfxZD2016268.

\section{Statement of conflict of interest}

We declare that there is no conflict of interests regarding the publication of this article.

\section{REFERENCES}

Brown, A.F., McKinnon, D. and Chu, K., 2001. Emergency department anaphylaxis: A review of 142 patients in a single year. J. Allergy Clin. Immunol., 108: 861-866. https://doi.org/10.1067/ mai.2001.119028

Decker, W.W., Campbell, R.L., Manivannan, V., Luke, A., Sauver, J.L.S., Weaver, A., Bellolio, M.F., Bergstralh, E.J., Stead, L.G. and Li, J.T.C., 2008. The etiology and incidence of anaphylaxis in Rochester, Minnesota:a report from the Rochester Epidemiology Project. J. Allergy Clin. Immunol.,
122: 1161-1165. https://doi.org/10.1016/j. jaci.2008.09.043

Evans, D.A., 1989. N-acetyltransferase. Pharmacol. Therapeut., 42: 157-234. https://doi. org/10.1016/0163-7258(89)90036-3

Falkner, J.A., Kachma, M., Veine, D.M., Walker, A., Strahler, J.R. and Andrews, P.C., 2007. Validated MALDI-TOF/TOF mass spectra for protein standards. J. Am. Soc. Mass Spectr., 18: 850-885. https://doi.org/10.1016/j.jasms.2007.01.010

Gjerde, D.T. and Fritz, J.S., 2000. Ion chromatography. Wiley-VCH, Weinheim, Germany, pp. 81-97.

Gupta, R., Sheikh, A., Strachan, D.P. and Anderson, H.R., 2007. Time trends in allergic disorders in the UK. Thorax, 62: 91-96. https://doi.org/10.1136/ thx.2004.038844

Guo, Y., Wu, W., Wang, H., Guo, X. and Xu, Y., 2018. The expression of IL-18R $\alpha$ in Inferior mesenteric ganglion of female goat. Pakistan J. Zool., 50: 671-678. http://dx.doi.org/10.17582/journal. pjz/2018.50.2.671.678

Hamish, S., 1989. Ion chromatography. Plenum Press, New York, America, pp. 376.

Heerma, W. and Kulik, W., 1988. Identification of amino acids in the fast atom bombardment mass spectra of peptides. Biomed. Environ. Mass. Sp., 16: 155-159. https://doi.org/10.1002/bms.1200160127

Hein, D.W., 2002. Molecular genetics and function of NAT1 and NAT2: Role in aromatic amine metabolism and carcinogenesis. Mutat. Res., 506: 65-77. https://doi.org/10.1016/S00275107(02)00153-7

Ispano, M., Scibilia, J., Ansaloni, R., Rotondo, F., Vannucci, L. and Ortolani, C., 1998. Definition and classification of food allergy and intolerance. Rev. Fr. Allergol., 138: 179-182. https://doi.org/10.1016/ S0335-7457(98)80096-8

Kanny, G., Moneret-Vautrin, D.A., Flabbe, E.J., Beaudouin, E., Morisset, M. and Thevenin, F., 2001. Population study of food allergy in France. $J$. Allergy Clin. Immunol., 108: 133-140. https://doi. org/10.1067/mai.2001.116427

Karas, M. and Kruger, R., 2003. Ion formation in MALDI: The cluster ionization mechanism. Chem. Rev., 103: 427-440. https://doi.org/10.1021/ cr010376a

Li, D., Siriamornpun, S., Wahlqvist, M.L., Mann, N.J. and Sinclair, A.J., 2005. Lean meat and heart health. Asia-Pac. J. clin. Nutr., 14: 113-119.

Mann, M. and Jensen, O.N., 2003. Proteomic analysis of post-translational modifications. Nat. Biotechnol., 21: $255-261$. https://doi.org/10.1038/nbt0303-255 
May, C.D., 1983. Immunologic versus toxic adverse reactions to food stuffs. Annls. Alleygy, 51: 267268.

Piraud, M., Vianey-Saban, C., Petritis, K., Elfakir, C., Steghens, J., Morla, A. and Bouchu, D., 2003. ESIMS/MS analysis of underivatized amino acids: A new tool for the diagnosis of inherited disorders of amino acid metabolism, fragmentation study of 79 molecules of biological interest in positive and negative ionization mode. Rapid Commun. Mass Sp., 17: 1297-1311. https://doi.org/10.1002/ rem. 1054

Robards, K., Jackson, P.E. and Haddad, P.A., 1995. Principles and practice of modern chromatographic methods, $1^{\text {st }}$ Edition. Academic Press, London, England, pp. 61-64.

Samyn, B., Debyser, G., Sergeant, K., Devreese, B. and Beeumen, J.V., 2004. A case study of de novo sequence analysis of $\mathrm{N}$-sulfonated peptides by MALDI TOF/TOF mass spectrometry. J. Am. Soc. Mass Spectr., 5: 1838-1852. https://doi. org/10.1016/j.jasms.2004.08.010

Ragione, F.D. and Pegg, A.E., 1982. Purification and characterization of spermidine/spermine N1acetyltransferase from rat liver. Biochemistry, 21: 6152-6158. https://doi.org/10.1021/bi00267a020

Richard, J.S. and Simpson, R.J., 2002. Protains and proteomics: A laboratory manual. Cold Spring Harbor Laboratory Press, New York, America, pp. 91-191.

Sampson, H.A., 2000. Food anaphylaxis. Br. med. Bull., 56: 925-935. https://doi. org/10.1258/0007142001903607

Samarten, S., Marcos, A. and Chandra, R.K., 2001. Food hypersensitivity. Nutr. Res., 21: 473-497. https://doi.org/10.1016/S0271-5317(00)00300-6

Sicherer, S.H., Munoz-Furlong, A. and Sampson, H.A., 2004. Prevalence of seafood allergy in the United States determined by a random telephone, survey. J. Allergy clin. Immunol., 114: 159-165. https://doi. org/10.1016/j.jaci.2004.04.018

Skoog, D.A., 2007. Principles of instrumental analysis, $6^{\text {th }}$ ed. Thompson Brooks, Belmont, CA, America, pp. 335-361.

Smit, D.V., Cameron, P.A. and Rainer, T.H., 2005. Anaphylaxis presentations to an emergency department in Hong Kong: Incidence and predictors of biphasic reactions. Emerg. med. J., 28: 381-388. https://doi.org/10.1016/j.jemermed.2004.11.028

Soga, T. and Heiger, D., 2000. Amino acid analysis by capillary electrophoresis electrospray ionization mass spectrometry. Anal. Chem., 72: 1236-1241. https://doi.org/10.1021/ac990976y

Stephanie, P.D., Millan-Agorio, M. and Kandiyoti, H., 2007. Probing size exclusion mechanisms of complex hydrocarbon mixtures: The effect of altering eluent compositions. Energy Fuels, 2: 3484-3489.

Untersmayr, E. and Jensen-Jarolim, E., 2008. The role of protein digestibility and antacids on food allergy outcomes. J. Allergy clin. Immunol., 121: 13011308. https://doi.org/10.1016/j.jaci.2008.04.025

Vatsis, K.P., Weber, W.W., Bell, D.A., Dupret, J.M., Evans, D.A., Grant, D.M., Hein, D.W., Lin, H.J., Meyer, U.A. and Relling, M.V., 1995. Nomenclature for N-acetyltransferases. Pharmacogenetics, 5: 1-36. https://doi.org/10.1097/00008571199502000-00001

Weiss, J., 2005. Handbook of ion chromatography, $3^{\text {rd }}$ ed. Wiley-VCH, Weinheim, Germany, pp. 359-371.

Williams, P., 2007. Nutritional composition of red meat. Nutr. Dietet., 64: 113-119. https://doi.org/10.1111/ j.1747-0080.2007.00197.x

Wohlleb, J.C., Hunter, C.F., Blass, B., Kadlubar, F.F., Chu, D.Z. and Lang, N.P., 1990. Aromatic amine acetyltransferase as a marker for colorectal cancer: Environmental and demographic associations. Int. J. Cancer, 46: 22-30. https://doi.org/10.1002/ ijc. 2910460107

Young, E., Stoneham, M.D., Petruckevitch, A., Barton, J. and Rona, R.A., 1994. Population study of food intolerance. Lancet, 343: 1127-1130. https://doi. org/10.1016/S0140-6736(94)90234-8 